Review

\title{
Green tea extract for prevention of prostate cancer progression in patients on active surveillance
}

\author{
Nagi B. Kumar ${ }^{1}$, Shohreh I. Dickinson ${ }^{2}$, Michael J. Schell ${ }^{3}$, Brandon J. Manley ${ }^{4}$, \\ Michael A. Poch ${ }^{4}$ and Julio Pow-Sang ${ }^{4}$ \\ ${ }^{1}$ H. Lee Moffitt Cancer Center \& Research Institute, Inc., Cancer Epidemiology, MRC/CANCONT, Tampa, FL 33612-9497, USA \\ ${ }^{2}$ H. Lee Moffitt Cancer Center \& Research Institute, Inc., Pathology Anatomic MMG, WCB-GU PROG, Tampa, FL 33612-9497, \\ USA \\ ${ }^{3} \mathrm{H}$. Lee Moffitt Cancer Center \& Research Institute, Inc., Biostatics and Bioinformatics, MRC-BIOSTAT, Tampa, FL 33612- \\ 9497, USA \\ ${ }^{4} \mathrm{H}$. Lee Moffitt Cancer Center \& Research Institute, GU Oncology MMG, Tampa, FL 33612-9497, USA \\ Correspondence to: Nagi B. Kumar, email: nagi.kumar@moffitt.org \\ Keywords: chemoprevention; prostate cancer; active surveillance; green tea catechins; prostate cancer progression \\ Received: October 03, $2018 \quad$ Accepted: December 10,2018Ｐublished: December 28, 2018 \\ Copyright: Kumar et al. This is an open-access article distributed under the terms of the Creative Commons Attribution License \\ 3.0 (CC BY 3.0), which permits unrestricted use, distribution, and reproduction in any medium, provided the original author and \\ source are credited.
}

\section{ABSTRACT}

Background: Active surveillance (AS) has evolved as a management strategy for men with low grade prostate cancer ( $\mathrm{PCa}$ ). However, these patients report anxiety, doubts about the possible progression of the disease as well as higher decisional conflict regarding selection of active surveillance, and have been reported to ultimately opt for treatment without any major change in tumor characteristics. Currently, there is a paucity of research that systematically examines alternate strategies for this target population.

Methods: We conducted a review the evidence from epidemiological, in vitro, preclinical and early phase trials that have evaluated green tea catechins (GTC) for secondary chemoprevention of prostate cancer, focused on men opting for active surveillanceof low grade PCa.

Results: Results of our review of the in vitro, preclinical and phase I-II trials, demonstrates that green tea catechins (GTC) can modulate several relevant intermediate biological intermediate endpoint biomarkers implicated in prostate carcinogenesis as well as clinical progression of $\mathrm{PCa}$, without major side effects.

Discussion: Although clinical trials using GTC have been evaluated in early phase trials in men diagnosed with High-Grade Prostatic Intraepithelial Neoplasia, Atypical Small Acinar Proliferation and in men with localized disease before prostatectomy, the effect of GTC on biological and clinical biomarkers implicated in prostate cancer progression have not been evaluated in this patient population.

Conclusion: Results of these studies promise to provide a strategy for secondary chemoprevention, reduce morbidities due to overtreatment and improve quality of life in men diagnosed with low-grade PCa.

\section{INTRODUCTION}

Prostate cancer $(\mathrm{PCa})$ remains, the most common non-cutaneous malignancy among men in the United States [1]. It is estimated that there will be 164,690 new cases of $\mathrm{PCa}$ in the United States (US) in 2018. The American Cancer Society estimates that in 2018, 29,430 men will die from this disease [1]. With an increase in utilizing serum concentrations of prostate specific antigen (PSA) for screening and early detection of PCa over the 
past two decades, a significant increase in the detection of low-grade prostate cancers has been observed. Recent data has demonstrated that these low grade tumors (Gleason $\leq 6$ ) pose little or no risk of either metastatic spread or death [2-5]. On the [2-5] other hand, over treatment is a well-recognized consequence of early detection of $\mathrm{PCa}$, particularly for those men with low grade PCa who are at low risk for aggressive or lethal disease and who may be now exposed to morbidities of over treatment with little or no benefit of cancer-specific survival [4, 6]. Active surveillance (AS) has thus evolved as a recommended management strategy for men with low risk disease, providing the benefit of an individualized approach of carefully monitoring disease progression using PSA kinetics, periodic biopsies and possibly surveillance MRI, sufficient to permit timely therapeutic intervention. Using this approach, in a large cohort of men on active surveillance followed over 15 years, Klotz et al., (2015) [7] demonstrated a $98 \%$ disease-specific survival for Gleason $3+3$ tumors. Other large cohort prospective studies have confirmed the safety and relative effectiveness of this approach [8].

However, several major challenges have been identified in this patient population on AS. Based on the results of the US National Cancer data base (2010-2011) [9], challenges to active surveillance include concerns about undergrading and a significant variation in criteria used to define men at low risk and eligible for active surveillance. For example, of men with prostate cancer, $39.8 \%$ vs. $28.5 \%$ vs. $10.7 \%$ were determined to be low risk and eligible for active surveillance by Klotz (least stringent) [10], D’Amico (intermediate stringent) [11] and modified Epstein criteria (Most stringent). Additionally, the percentage of men receiving active surveillance was much lower in the national sample evaluated by Maurice et al. (2015) [9], across all criteria: 6.5\%, 7.4\% and $12.1 \%$, demonstrating continued overtreatment that has not substantially changed based from evidence used in the 2012 recommendations [12]. Other challenges include patient-related factors such as anxiety, depression, doubts about the possible progression of the disease as well as higher decisional conflict regarding selection of active surveillance $[13,14]$, reported by this cohort. Men on active surveillance have thus been reported to ultimately opt for treatment without any major change in tumor characteristics. On the other hand, men on active surveillance are a subgroup, who are highly motivated and eager to make positive lifestyle changes, including strategies to further reduce their risk of $\mathrm{PCa}$ progression [14-16] providing an opportunity for preventing progression through pharmacologic means [17-19]. Taking into consideration these caveats, men on active surveillance are an ideal target for chemoprevention interventions with promising agents, to potentially further reduce progression to later stage disease as well as anxiety during the period of AS. Currently, there is a paucity of research that systematically examines agents for chemoprevention men on AS, underscoring the need to identify other novel agents for prostate cancer chemoprevention in this target population that is closely monitored during the active surveillance period.

The goal for prostate cancer chemoprevention is to utilize a systematic, broad spectrum approach [20] that involves using a botanical that has been shown to have an: (a) bioavailable; (b) excellent safety profile; (c) produces robust targeting of relevant and multiple molecular pathways; and (d) modulates intermediate endpoint biomarkers implicated in clinical progress of $\mathrm{PCa}$ - an approach that may be more effective than agents evaluated to date.

\section{RESULTS}

Results from epidemiological data have shown that the mortality rates of $\mathrm{PCa}$ is the lowest in Asia, where 20\% of the world's green tea is consumed [4]. However, once these habits are abandoned upon migration to the West, including to the United States, the risk of PCa appears to increase [21]. However, case-control and cohort studies addressing the relationship between GTC consumption and $\mathrm{PCa}$ risk have been mixed potentially attributed to varying formulations of catechins evaluated [22, 23].

(GTCs) include (-)-epigallocatechin-3-gallate (EGCG), (-)-epicatechin (EC), (-)-epigallocatechin (EGC), and (-)-epicatechin-3-gallate (ECG). Among these compounds, laboratory studies have identified EGCG as the most potent modulator of molecular pathways thought to be relevant to prostate carcinogenesis [21-25]. EGCG has been found to affect several cancerrelated proteins including Cyclin-dependent kinase inhibitor p27 (p27), Bcl-2 or Bcr-Abl oncoproteins, Bax, matrix metalloproteinases (MMP-2 and MMP-9) [26] the androgen receptor, EGF receptor, Activator proteins 1(AP1), and some cell cycle regulators. Based on these studies of GTCP in cell culture systems, Adhami et al. [26], were able to demonstrate that EGCG in GTP induces apoptosis, cell growth inhibition and cyclin kinase inhibitor Cyclin-dependent kinase inhibitor p21 (WAF)1/p21-mediated cell cycle-dysregulation. Using cDNA microarrays, they also observed the EGCG treatment of LNCaP cells results in induction of genes that exhibit the growth-inhibitory effects and repression of genes that belong to the G-protein signaling network [26]. It is well established that the ubiquitin/proteasome pathway plays a critical function in the regulation of apoptosis. We and others have demonstrated that although there are several mechanisms by which EGCG may modulate prostate carcinogenesis, the catechin-EGCG potently and selectively inhibits the proteasome activity in intact human cells and ultimately results in the accumulation of B- $\alpha$ and p27 proteins, and growth arrest [27-31].

This inhibition of proteasome activity by EGCG occurred at or near physiological concentrations similar to that found in the body fluids of green tea drinkers. We have observed that Polyphenon E (a mixture of tea 
catechins), similar in composition to the GTC proposed in this trial, specifically inhibits the proteasomal chymotrypsin-like activity with an IC50 value of 7 $\mu \mathrm{M}$ [18]. The IC50 value for trypsin-like activity was above $100 \mu \mathrm{M}$, demonstrating that Polyphenon $\mathrm{E}$ preferentially inhibits the proteasomal chymotrypsin-like activities. Data from our studies implies that indeed, the proteasome is potentially a PCa-related molecular target of GTC. Thus the inhibition of the proteasome activity by the catechin EGCG present in GTC leading to apoptosis, ultimately impacting the prostate carcinogenesis.

We and others have reported evidence from cell culture and preclinical models that suggest that GTC inhibit proliferation and cell cycle events and induces apoptosis through multiple mechanisms including antioxidant and anti-inflammatory activity [24, 32-34]. Preclinical studies of GTCs [26, 35-39], including from our preliminary studies, have shown significant reductions in tumor size and multiplicity in the prostate cancer Trangenic adenocarcinoma of the mouse prostate (TRAMP) models. Gupta et al. [35], showed that an oral infusion of GTP extract at a human achievable dose (equivalent to six cups of green tea per day) in a TRAMP mouse model delayed primary $\mathrm{PCa}$ incidence, including tumor burden that was serially assessed through the study using Magnetic Resonance Imaging (MRI). In addition to observing a decrease in prostate weight by $64 \%$ of baseline, intervention with GTP inhibited serum insulin-like growth factor-I (IGF-I) and restored levels of insulin-like growth factor binding protein-3 levels (IGFBP-3). Additionally, a significant reduction in the expression of Proliferating Cell Nuclear Antigen (PCNA) proteins was observed in the prostate of GTP-fed animals compared to water-fed TRAMP mice was observed, GTP fed mice also demonstrated significant apoptosis, potentially leading to reduction in dissemination of cancer cells, ultimately inhibiting development, progression and metastasis of $\mathrm{PCa}$ to distant organ sites. Using the TRAMP mouse model, Suttie et al., have reported that oral administration of whole GTPs (vs. the pure form of the catechin -EGCG) was highly bioavailable [26, 29, 35-37, 39] compared to EGCG alone [39]. We evaluated the safety and effectiveness of a standardized formulation of GTP-Polyphenon E at various doses, $(200,500$, and $1,000 \mathrm{mg} / \mathrm{kg} /$ day), in reducing the progression of prostate cancer in a TRAMP mouse model. We reported that in TRAMP mice treated with all doses of Polyhenon E, the number and size of PCa tumors significantly decreased compared with untreated animals. In 32 weeks, 100\% of TRAMP mice that were untreated, were observed to have PCa metastasis to distant sites $(8 / 8)$. On the other hand only $13 \%$ of mice $(2 / 16)$ treated with high-dose (1000 mgs/Kg/day) Polyphenon E were observed to PCa metastasis to distant sites. Our team, in addition, observed that treatment with Polyphenon E significantly inhibited metastasis in TRAMP mice in a dose-dependent manner
$(\mathrm{P}=0.0003)$. Thus, a 32 week treatment with standardized formulation of GTC was well tolerated with no evidence of toxicity in C57BL/6J mice [38].

Early phase trials completed in the past decade [40-51] have shown that GTC containing doses of the catechin, EGCG ranging from 200 to $1200 \mathrm{mg}$ a day is well tolerated. Although most catechins as measured in plasma appeared in low to non-detectable concentrations, EGCG appears to be the most bioavailable in the plasma [52-54], with greater bioavailability observed in a fasting state [45]. However, greater gastrointestinal toxicities have been reported when GTC is consumed in a fasting state compared when consumed in a fed state. Similarly, the bioavailability and tolerance to a multiple dosing schedule compared to a single daily dose of EGCG has been reported in phase II trials [32, 40, 41, 48]. Phase I/ II [40-51] studies of less than 3 month duration, have demonstrated bioavailability as well as drug effects of GTC at doses ranging from 200-1200 mg EGCG in GTC per day. Findings from our study (decaffeinated GTC $200 \mathrm{mgs}$ BID of EGCG) and Bettuzzi et al. [40, 48], (600 mgs EGCG per day) have demonstrated that a daily intake of standardized formulation administered for 12 months, with food (nonfasting), accumulates in plasma, reduces serum PSA [48] and cumulative rate of progression to $\mathrm{PCa}$ with no toxicities. However, these were primary chemoprevention trials with subjects diagnosed with HGPIN or ASAP and not cancer. In three (3) randomized trials $[32,33,55]$ using GTC as a standardized supplement or beverage with EGCG content ranging from 500- $800 \mathrm{mgs}$ ) for a maximum duration of intervention of 6 weeks administered prior to prostatectomy in men diagnosed with localized PCa, GTC were well tolerated with only mild toxicities observed. Most adverse events that have been reported with GTC have included mild nausea observed at doses of $1200 \mathrm{mgs}$ EGCG dose/day and when patients were fasting. This has informed future clinical trials to use GTP formulations containing no more than $800 \mathrm{mg}$ of EGCG per day with instructions to patients to consume the catechins with food. Others have shown that GTC administered for 4 weeks did not after drug metabolizing enzymes $[44,56]$ including CYP2D6 or CYP3A4 activity [57].

Virtually all active surveillance programs continue to monitor PSA serially. PSA kinetic measurements such as PSA velocity (PSAV) and PSA doubling time Prostate specific antigen doubling time (PSADT) have been extensively evaluated as predictors of progression $[19,58]$. In several active surveillance programs, PSA kinetics was historically used as a trigger for intervention with a significant association between PSA kinetics and progression to treatment $[59,60]$. However, studies have shown that PSA kinetics are not a reliable predictor of biopsy reclassification during active surveillance [61, 62]. As a result, PSA kinetics is now considered trigger for further diagnostic evaluation rather than as a trigger for intervention [63]. Patel et al. [64], showed that men with 
multiple successive PSAV measurements $>0.4 \mathrm{ng} / \mathrm{ml} /$ year have a significantly greater risk of biopsy reclassification beyond the first 2 years of active surveillance [65]. Thus, men with stable disease on active surveillance for several years may benefit from the use of PSA kinetics [64, 66, 67]. Other PSA measurement such as Prostate Specific Antigen Density (PSAD) at the time of diagnostic biopsy can be used to predict progression and is predictive of biopsy reclassification at subsequent surveillance [68], and can thus be used to predict progression during active surveillance. Approved by the Food and Drug Administration (FDA) in 2012 as an aid in early PCa detection [69]. The Prostate Health Index (phi) is an adjunctive PSA-based measurement combining total, free, and [-2] proPSA using a mathematical formula and has been shown to outperform PSA and free PSA for identifying clinically significant $\mathrm{PCa}$ [70], and a predictor of biopsy reclassification $[34,71]$. Additional studies are needed to identify how phi can be best utilized, possibly in conjunction with imaging, to help monitor men during active surveillance [61-63, 67]. Bettuzzi and colleagues reported a significant reduction in prostate cancer in men with HGPIN randomized to receive one-year of EGCG $[40,41]$. We reported the results of a randomized, placebocontrolled phase II clinical trial examining the safety and effectiveness of Polyphenon E (PolyE), a mixture of GTCs, containing $400 \mathrm{mg}$ (-)-epigallocatechin-3gallate (EGCG) per day. We recruited and treated 97 men diagnosed with HGPIN and/or atypical small acinar proliferation (ASAP). We observed a greater number of men progressed to prostate cancer in 1 year in the placebo arm compared to men treated with Polyphenon E (5 of 49 (Poly E) versus 9 of 48 (placebo), $\mathrm{P}=0.25$ ). Among men with HGPIN without ASAP at baseline, examining a pre-specified secondary endpoint of cumulative rate of progression from HGPIN to prostate cancer or ASAP, we observed a significantly greater number of men progressing to prostate cancer in the Poly E treated arm compared to the placebo ( 3 of 26 (PolyE) versus 10 of 25 (placebo), $\mathrm{P}<0.024)$. We also observed a a significant decrease in serum PSA with PolyE treatment $[-0.87$ $\mathrm{ng} / \mathrm{mL} ; 95 \%$ confidence intervals $(\mathrm{CI}),-1.66$ to -0.09 ] compared to placebo $[48,72]$. We observed a significant decrease in serum PSA in men on the PolyE arm $[-0.87$ $\mathrm{ng} / \mathrm{mL} ; 95 \%$ confidence intervals $(\mathrm{CI}),-1.66$ to -0.09 ] compared to the placebo arm $[48,72]$. Similar results were observed by Henning, et al. who also demonstrated statistically significant reduction in serum PSA with GTC. $(P=0.04)$ [32]. In addition to reduction of serum PSA, McLarty et al. [33], showed a significant reduction in Hepatocyte Growth Factor (HGF), and Vascular Endrothelial Growth Factor (VEGF) after treatment with GTC containing a doe of 800 mgs EGCG (Polyphenon E) targeting PCa patients, with no elevation of liver enzymes.

In summary, epidemiological, laboratory and early phase clinical trials over the past two decades have demonstrated that formulations of GTC containing over $50 \%$ catechins in the form of EGCG administered to men at high risk or men with localized $\mathrm{PCa}$, is bioavailable in plasma, reduces serum PSA, modulates proliferative and apoptotic intermediate endpoint biomarkers implicated in prostate carcinogenesis and the cumulative rate of progression to prostate cancer with no toxicities, including liver enzymes. Standardized formulations of GTC thus appears to be promising agents for prostate cancer chemoprevention.

\section{DISCUSSION}

The current recommendations to manage patients with low grade PCa is active surveillance while being carefully monitored for disease progression using PSA kinetics, periodic biopsies for histologic progression, sufficient to permit timely therapeutic intervention. However, concerns about under-grading, variations in criteria for active surveillance eligibility, patientrelated factors such as anxiety, depression, doubts about the possible progression of the disease as well as higher decisional conflict regarding selection of active surveillance result in men on active surveillance ultimately opt for treatment without any major change in tumor characteristics. On the other hand, men on active surveillance are a subgroup, who are highly motivated and eager to make positive lifestyle changes, including strategies to further reduce their risk of $\mathrm{PCa}$ progressionproviding an opportunity for preventing progression through pharmacologic means.

Previous chemoprevention strategies targeting men on active surveillance have included large phase III trials with 5-alpha-reductase inhibitors, finasteride and dutasteride [19, 73, 74]. Although these agents significantly reduced the risk of prostate cancer progression, their use was also associated with increased detection of high-grade disease, severely limiting their clinical adoption [74]. Another large, phase III prostate cancer prevention clinical trial showed no benefit for long-term supplementation with the trace element Se, given in the form of selenomethionine, or vitamin $\mathrm{E}$, either individually or in combination. However, a significant increase in prostate cancer was observed among men randomized to receive vitamin E alone [75]. Currently, strategies using dietary interventions (The Men's Eating and Living (MEAL) Study: A Randomized Trial of Diet to Alter Disease Progression in Prostate Cancer Patients on Active Surveillance) [76], as well as, pomegranate fruit extract (https://clinicaltrials. gov/ Identifier: NCT02095145) targeting the active surveillance population are ongoing with results of these trials pending. However, to date, there is minimal evidence available of any one agent or strategy that has been found to be effective for chemoprevention for men on active surveillance for PCa. There is thus a paucity of research 
that systematically examines agents for chemoprevention men on active surveillance that are available, underscoring the need to identify and test other novel agents for prostate cancer chemoprevention in this target population. Although green tea catechins have been examined in clinical trials targeting men with HGPIN, ASAP and in men prior to prostatectomy, to-date, the effect of GTP on biological and clinical intermediate endpoint biomarkers implicated in prostate cancer progression have not been evaluated in men on active surveillance. Based on the in vitro, preclinical and phase I-II trials, green tea catechins, GTC appear be a promising agent for prostate cancer chemoprevention, establishing the evidence needed to be further test this agent in the active surveillance population, for whom, currently, there are no options for reducing their risk.

\section{MATERIALS AND METHODS}

The goal of the current review is to evaluate the current evidence from epidemiological, in vitro, preclinical and early phase trials completed by our team and others that have established the evidence needed for further development of Green Tea C (GTC) for secondary chemoprevention of prostate cancer targeting men on active surveillance for prostate cancer. We searched eligible studies conducted in the past 2 decades up to October 2018 in the PUBMED, MEDLINE and EMBASE. We included in vitro, preclinical and all prospective, controlled interventional studies and observational studies, which evaluated the associations between green tea catechin consumption and risk of prostate cancer incidence, modulation of intermediate endpoint biomarkers implicated in prostate carcinogenesis, prostate cancer progression or that reported on cancer mortality. The review was limited to a GTC in prostate carcinogenesis and not other additional agents or diseases, including other cancers. A minimum of two investigators independently reviewed the data according to the established inclusion criteria. Additionally, the methodological quality of the studies was assessed by all authors specifically as it related to modulation of prostate carcinogensis by green tea catechins.

\section{CONCLUSIONS}

Systematically evaluating the effectiveness and safety of novel agents such as green tea catechins, which have been well characterized in laboratory and early phase clinical trials, may inform the development of phase III clinical trials and ultimately provide strategies for chemoprevention in men on active surveillance for prostate cancer, for whom, currently, there are no options for reducing their risk.

\section{CONFLICTS OF INTEREST}

None of the authors have any potential or competing interests.

\section{FUNDING}

This is supported by National Institute of Health Grant 5P30CA076292-20.

\section{REFERENCES}

1. http://www.cancer.org/Cancer/ProstateCancer/ DetailedGuide/prostate-cancer-key-statistics.

2. Bruinsma SM, Bangma $\mathrm{CH}$, Carroll PR, Leapman MS, Rannikko A, Petrides N, Weerakoon M, Bokhorst LP, Roobol MJ, Movember GAP3 consortium. Active surveillance for prostate cancer: a narrative review of clinical guidelines. Nat Rev Urol. 2016; 13: 151-67. https:// doi.org/10.1038/nrurol.2015.313.

3. Ip S, Dahabreh IJ, Chung M, Yu WW, Balk EM, Iovin RC, Mathew P, Luongo T, Dvorak T, Lau J. An evidence review of active surveillance in men with localized prostate cancer. Evid Rep Technol Assess (Full Rep). 2011; 204: 1-341.

4. Klotz L. Active surveillance for prostate cancer: for whom? J Clin Oncol. 2005; 23: 8165-9. https://doi.org/10.1200/ JCO.2005.03.3134.

5. Thompson I, Thrasher JB, Aus G, Burnett AL, Canby-Hagino ED, Cookson MS, D'Amico AV, Dmochowski RR, Eton DT, Forman JD, Goldenberg SL, Hernandez J, Higano CS, et al. Guideline for the management of clinically localized prostate cancer: 2007 update. J Urol. 2007; 177: 2106-31. https://doi. org/10.1016/j.juro.2007.03.003.

6. Hamdy FC, Donovan JL, Neal DE. 10-Year Outcomes in Localized Prostate Cancer. N Engl J Med. 2017; 376: 180. https://doi.org/10.1056/NEJMc1614342.

7. Klotz L, Zhang L, Lam A, Nam R, Mamedov A, Loblaw A. Clinical results of long-term follow-up of a large, active surveillance cohort with localized prostate cancer. J Clin Oncol. 2010; 28: 126-31. https://doi.org/10.1200/ JCO.2009.24.2180.

8. Klotz L. Active surveillance for low-risk prostate cancer. Curr Urol Rep. 2015; 16: 24. https://doi.org/10.1007/ s11934-015-0492-z.

9. Maurice MJ, Abouassaly R, Kim SP, Zhu H. Contemporary Nationwide Patterns of Active Surveillance Use for Prostate Cancer. JAMA Intern Med. 2015; 175: 1569-71. https://doi. org/10.1001/jamainternmed.2015.2835. 
10. Klotz L. Active surveillance and focal therapy for low-intermediate risk prostate cancer. Transl Androl Urol. 2015; 4: 342-54. https://doi.org/10.3978/j. issn.2223-4683.2015.06.03.

11. D'Amico AV. Personalizing the Use of Active Surveillance As an Initial Approach for Men With Newly Diagnosed Prostate Cancer. J Clin Oncol. 2015; 33: 3365-6. https:// doi.org/10.1200/JCO.2015.63.6118.

12. Cooperberg MR, Carroll PR. Trends in Management for Patients With Localized Prostate Cancer, 19902013. JAMA. 2015; 314: 80-2. https://doi.org/10.1001/ jama.2015.6036.

13. Orom H, Underwood W 3rd, Biddle C. Emotional Distress Increases the Likelihood of Undergoing Surgery among Men with Localized Prostate Cancer. J Urol. 2017; 197: 350-5. https://doi.org/10.1016/j.juro.2016.08.007.

14. Watts S, Leydon G, Eyles C, Moore CM, Richardson A, Birch B, Prescott P, Powell C, Lewith G. A quantitative analysis of the prevalence of clinical depression and anxiety in patients with prostate cancer undergoing active surveillance. BMJ Open. 2015; 5: e006674. https://doi. org/10.1136/bmjopen-2014-006674.

15. Avery KN, Donovan JL, Horwood J, Neal DE, Hamdy FC, Parker C, Wade J, Lane A. The importance of dietary change for men diagnosed with and at risk of prostate cancer: a multi-centre interview study with men, their partners and health professionals. BMC Fam Pract. 2014; 15: 81. https:// doi.org/10.1186/1471-2296-15-81.

16. Horwood JP, Avery KN, Metcalfe C, Donovan JL, Hamdy FC, Neal DE, Lane JA. Men's knowledge and attitudes towards dietary prevention of a prostate cancer diagnosis: a qualitative study. BMC Cancer. 2014; 14: 812. https://doi. org/10.1186/1471-2407-14-812.

17. Kelloff GJ, Lieberman R, Steele VE, Boone CW, Lubet RA, Kopelovitch L, Malone WA, Crowell JA, Sigman CC. Chemoprevention of prostate cancer: concepts and strategies. Eur Urol. 1999; 35: 342-50.

18. Kumar N, Chornokur G. Molecular Targeted Therapies Using Botanicals for Prostate Cancer Chemoprevention. Transl Med (Sunnyvale). 2012; Suppl 2: 005. https://doi. org/10.4172/2161-1025.S2-005.

19. Lieberman R. Prostate cancer chemoprevention: Strategies for designing efficient clinical trials. Urology. 2001; 57: 224-9.

20. Block KI, Gyllenhaal C, Lowe L, Amedei A, Amin A, Amin A, Aquilano K, Arbiser J, Arreola A, Arzumanyan A, Ashraf SS, Azmi AS, Benencia F, et al. Designing a broadspectrum integrative approach for cancer prevention and treatment. Semin Cancer Biol. 2015; 35: S276-S304. https:// doi.org/10.1016/j.semcancer.2015.09.007.

21. Ito K. Prostate cancer in Asian men. Nat Rev Urol. 2014; 11: 197-212. https://doi.org/10.1038/nrurol.2014.42.

22. Jian L, Xie LP, Lee AH, Binns CW. Protective effect of green tea against prostate cancer: a case-control study in southeast China. Int J Cancer. 2004; 108: 130-5. https://doi. org/10.1002/ijc.11550.

23. Yuan JM. Cancer prevention by green tea: evidence from epidemiologic studies. Am J Clin Nutr. 2013; 98: 1676S81S. https://doi.org/10.3945/ajen.113.058271.

24. Connors SK, Chornokur G, Kumar NB. New insights into the mechanisms of green tea catechins in the chemoprevention of prostate cancer. Nutr Cancer. 2012; 64: 4-22. https://doi.org/10.1080/01635581.2012.630158.

25. Lee J, Demissie K, Lu SE, Rhoads GG. Cancer incidence among Korean-American immigrants in the United States and native Koreans in South Korea. Cancer Control. 2007; 14: 78-85. https://doi.org/10.1177/107327480701400111.

26. Adhami VM, Siddiqui IA, Sarfaraz S, Khwaja SI, Hafeez BB, Ahmad N, Mukhtar H. Effective prostate cancer chemopreventive intervention with green tea polyphenols in the TRAMP model depends on the stage of the disease. Clin Cancer Res. 2009; 15: 1947-53. https://doi. org/10.1158/1078-0432.CCR-08-2332.

27. Kazi A, Daniel KG, Smith DM, Kumar NB, Dou QP. Inhibition of the proteasome activity, a novel mechanism associated with the tumor cell apoptosis-inducing ability of genistein. Biochem Pharmacol. 2003; 66: 965-76.

28. Kazi A, Wang Z, Kumar N, Falsetti SC, Chan TH, Dou QP. Structure-activity relationships of synthetic analogs of (-)-epigallocatechin-3-gallate as proteasome inhibitors. Anticancer Res. 2004; 24: 943-54.

29. Khan N, Mukhtar H. Modulation of signaling pathways in prostate cancer by green tea polyphenols. Biochem Pharmacol. 2013; 85: 667-72. https://doi.org/10.1016/j. bcp.2012.09.027.

30. Nam S, Smith DM, Dou QP. Ester bond-containing tea polyphenols potently inhibit proteasome activity in vitro and in vivo. J Biol Chem. 2001; 276: 13322-30. https://doi. org/10.1074/jbc.M004209200.

31. Smith DM, Wang Z, Kazi A, Li LH, Chan TH, Dou QP. Synthetic analogs of green tea polyphenols as proteasome inhibitors. Mol Med. 2002; 8: 382-92.

32. Henning SM, Wang P, Said JW, Huang M, Grogan T, Elashoff D, Carpenter CL, Heber D, Aronson WJ. Randomized clinical trial of brewed green and black tea in men with prostate cancer prior to prostatectomy. Prostate. 2015; 75: 550-9. https://doi.org/10.1002/pros.22943.

33. McLarty J, Bigelow RL, Smith M, Elmajian D, Ankem M, Cardelli JA. Tea polyphenols decrease serum levels of prostate-specific antigen, hepatocyte growth factor, and vascular endothelial growth factor in prostate cancer patients and inhibit production of hepatocyte growth factor and vascular endothelial growth factor in vitro. Cancer Prev Res (Phila). 2009; 2: 673-82. https://doi.org/10.1158/19406207.CAPR-08-0167.

34. Wang P, Aronson WJ, Huang M, Zhang Y, Lee RP, Heber D, Henning SM. Green tea polyphenols and metabolites in prostatectomy tissue: implications for cancer prevention. 
Cancer Prev Res (Phila). 2010; 3: 985-93. https://doi. org/10.1158/1940-6207.CAPR-09-0210.

35. Gupta S, Hastak K, Ahmad N, Lewin JS, Mukhtar H. Inhibition of prostate carcinogenesis in TRAMP mice by oral infusion of green tea polyphenols. Proc Natl Acad Sci U S A. 2001; 98: 10350-5. https://doi.org/10.1073/ pnas. 171326098 .

36. Harper CE, Patel BB, Wang J, Eltoum IA, Lamartiniere CA. Epigallocatechin-3-Gallate suppresses early stage, but not late stage prostate cancer in TRAMP mice: mechanisms of action. Prostate. 2007; 67: 1576-89. https://doi.org/10.1002/ pros.20643.

37. Khan N, Adhami VM, Mukhtar H. Review: green tea polyphenols in chemoprevention of prostate cancer: preclinical and clinical studies. Nutr Cancer. 2009; 61: 83641. https://doi.org/10.1080/01635580903285056.

38. Kim SJ, Amankwah E, Connors S, Park HY, Rincon M, Cornnell H, Chornokur G, Hashim AI, Choi J, Tsai YY, Engelman RW, Kumar N, Park JY. Safety and chemopreventive effect of Polyphenon E in preventing early and metastatic progression of prostate cancer in TRAMP mice. Cancer Prev Res (Phila). 2014; 7: 435-44. https://doi. org/10.1158/1940-6207.CAPR-13-0427-T.

39. Suttie A, Nyska A, Haseman JK, Moser GJ, Hackett TR, Goldsworthy TL. A grading scheme for the assessment of proliferative lesions of the mouse prostate in the TRAMP model. Toxicol Pathol. 2003; 31: 31-8. https://doi. org/10.1080/01926230390173842.

40. Bettuzzi S, Brausi M, Rizzi F, Castagnetti G, Peracchia G, Corti A. Chemoprevention of human prostate cancer by oral administration of green tea catechins in volunteers with high-grade prostate intraepithelial neoplasia: a preliminary report from a one-year proof-of-principle study. Cancer Res. 2006; 66: 1234-40. https://doi.org/10.1158/0008-5472. CAN-05-1145.

41. Brausi M, Rizzi F, Bettuzzi S. Chemoprevention of human prostate cancer by green tea catechins: two years later. A follow-up update. Eur Urol. 2008; 54: 472-3. https://doi. org/10.1016/j.eururo.2008.03.100.

42. Chow HH, Cai Y, Alberts DS, Hakim I, Dorr R, Shahi F, Crowell JA, Yang CS, Hara Y. Phase I pharmacokinetic study of tea polyphenols following single-dose administration of epigallocatechin gallate and polyphenon E. Cancer Epidemiol Biomarkers Prev. 2001; 10: 53-8.

43. Chow HH, Cai Y, Hakim IA, Crowell JA, Shahi F, Brooks CA, Dorr RT, Hara Y, Alberts DS. Pharmacokinetics and safety of green tea polyphenols after multiple-dose administration of epigallocatechin gallate and polyphenon E in healthy individuals. Clin Cancer Res. 2003; 9: 3312-9.

44. Chow HH, Hakim IA, Vining DR, Crowell JA, Cordova $\mathrm{CA}$, Chew WM, Xu MJ, Hsu CH, Ranger-Moore J, Alberts DS. Effects of repeated green tea catechin administration on human cytochrome P450 activity. Cancer
Epidemiol Biomarkers Prev. 2006; 15: 2473-6. https://doi. org/10.1158/1055-9965.EPI-06-0365.

45. Chow HH, Hakim IA, Vining DR, Crowell JA, RangerMoore J, Chew WM, Celaya CA, Rodney SR, Hara Y, Alberts DS. Effects of dosing condition on the oral bioavailability of green tea catechins after single-dose administration of Polyphenon $\mathrm{E}$ in healthy individuals. Clin Cancer Res. 2005; 11: 4627-33. https://doi. org/10.1158/1078-0432.CCR-04-2549.

46. Chow HH, Hakim IA, Vining DR, Crowell JA, Tome ME, Ranger-Moore J, Cordova CA, Mikhael DM, Briehl MM, Alberts DS. Modulation of human glutathione s-transferases by polyphenon e intervention. Cancer Epidemiol Biomarkers Prev. 2007; 16: 1662-6. https://doi. org/10.1158/1055-9965.EPI-06-0830.

47. Isbrucker RA, Edwards JA, Wolz E, Davidovich A, Bausch J. Safety studies on epigallocatechin gallate (EGCG) preparations. Part 2: dermal, acute and short-term toxicity studies. Food Chem Toxicol. 2006; 44: 636-50. https://doi. org/10.1016/j.fct.2005.11.003.

48. Kumar NB, Pow-Sang J, Egan KM, Spiess PE, Dickinson S, Salup R, Helal M, McLarty J, Williams CR, Schreiber F, Parnes HL, Sebti S, Kazi A, et al. Randomized, PlaceboControlled Trial of Green Tea Catechins for Prostate Cancer Prevention. Cancer Prev Res (Phila). 2015; 8: 879-87. https://doi.org/10.1158/1940-6207.CAPR-14-0324.

49. Pisters KM, Newman RA, Coldman B, Shin DM, Khuri FR, Hong WK, Glisson BS, Lee JS. Phase I trial of oral green tea extract in adult patients with solid tumors. J Clin Oncol. 2001; 19: 1830-8. https://doi.org/10.1200/ JCO.2001.19.6.1830.

50. Ullmann U, Haller J, Decourt JD, Girault J, Spitzer V, Weber P. Plasma-kinetic characteristics of purified and isolated green tea catechin epigallocatechin gallate (EGCG) after 10 days repeated dosing in healthy volunteers. Int J Vitam Nutr Res. 2004; 74: 269-78. https://doi. org/10.1024/0300-9831.74.4.269.

51. Ullmann U, Haller J, Decourt JP, Girault N, Girault J, Richard-Caudron AS, Pineau B, Weber P. A single ascending dose study of epigallocatechin gallate in healthy volunteers. J Int Med Res. 2003; 31: 88-101. https://doi. org/10.1177/147323000303100205.

52. Kapetanovic IM, Crowell JA, Krishnaraj R, Zakharov A, Lindeblad M, Lyubimov A. Exposure and toxicity of green tea polyphenols in fasted and non-fasted dogs. Toxicology. 2009; 260: 28-36. https://doi.org/10.1016/j.tox.2009.03.007.

53. Schmidt M, Schmitz HJ, Baumgart A, Guedon D, Netsch MI, Kreuter MH, Schmidlin CB, Schrenk D. Toxicity of green tea extracts and their constituents in rat hepatocytes in primary culture. Food Chem Toxicol. 2005; 43: 307-14. https://doi.org/10.1016/j.fct.2004.11.001.

54. Wu KM, Yao J, Boring D. Green tea extractinduced lethal toxicity in fasted but not in nonfasted 
dogs. Int J Toxicol. 2011; 30: 19-20. https://doi. org/10.1177/1091581810387445.

55. Nguyen MM, Ahmann FR, Nagle RB, Hsu CH, Tangrea JA, Parnes HL, Sokoloff MH, Gretzer MB, Chow HH. Randomized, double-blind, placebo-controlled trial of polyphenon $\mathrm{E}$ in prostate cancer patients before prostatectomy: evaluation of potential chemopreventive activities. Cancer Prev Res (Phila). 2012; 5: 290-8. https:// doi.org/10.1158/1940-6207.CAPR-11-0306.

56. Rendic S, Di Carlo FJ. Human cytochrome P450 enzymes: a status report summarizing their reactions, substrates, inducers, and inhibitors. Drug Metab Rev. 1997; 29: 413-580.

57. Donovan JL, Chavin KD, Devane CL, Taylor RM, Wang JS, Ruan Y, Markowitz JS. Green tea (Camellia sinensis) extract does not alter cytochrome p450 3A4 or 2D6 activity in healthy volunteers. Drug Metab Dispos. 2004; 32: 906-8. https://doi.org/10.1124/dmd.104.000083.

58. Tosoian JJ, Carter HB, Lepor A, Loeb S. Active surveillance for prostate cancer: current evidence and contemporary state of practice. Nat Rev Urol. 2016; 13: 205-15. https://doi. org/10.1038/nrurol.2016.45.

59. Adamy A, Yee DS, Matsushita K, Maschino A, Cronin A, Vickers A, Guillonneau B, Scardino PT, Eastham JA. Role of prostate specific antigen and immediate confirmatory biopsy in predicting progression during active surveillance for low risk prostate cancer. J Urol. 2011; 185: 477-82. https://doi.org/10.1016/j.juro.2010.09.095.

60. Soloway MS, Soloway CT, Williams S, Ayyathurai R, Kava B, Manoharan M. Active surveillance; a reasonable management alternative for patients with prostate cancer: the Miami experience. BJU Int. 2008; 101: 165-9. https:// doi.org/10.1111/j.1464-410X.2007.07190.x.

61. Ross AE, Loeb S, Landis P, Partin AW, Epstein JI, Kettermann A, Feng Z, Carter HB, Walsh PC. Prostatespecific antigen kinetics during follow-up are an unreliable trigger for intervention in a prostate cancer surveillance program. J Clin Oncol. 2010; 28: 2810-6. https://doi. org/10.1200/JCO.2009.25.7311.

62. Whitson JM, Porten SP, Hilton JF, Cowan JE, Perez N, Cooperberg MR, Greene KL, Meng MV, Simko JP, Shinohara K, Carroll PR. The relationship between prostate specific antigen change and biopsy progression in patients on active surveillance for prostate cancer. J Urol. 2011; 185: 1656-60. https://doi.org/10.1016/j.juro.2010.12.042.

63. Klotz L. Defining 'progression' and triggers for curative intervention during active surveillance. Curr Opin Urol. 2015; 25: 258-66.

64. Patel HD, Feng Z, Landis P, Trock BJ, Epstein JI, Carter HB. Prostate specific antigen velocity risk count predicts biopsy reclassification for men with very low risk prostate cancer. J Urol. 2014; 191: 629-37. https://doi.org/10.1016/j. juro.2013.09.029.

65. Iremashvili V, Manoharan M, Lokeshwar SD, Rosenberg DL, Pan D, Soloway MS. Comprehensive analysis of post-diagnostic prostate-specific antigen kinetics as predictor of a prostate cancer progression in active surveillance patients. BJU Int. 2013; 111: 396-403. https:// doi.org/10.1111/j.1464-410X.2012.11295.x.

66. San Francisco IF, Werner L, Regan MM, Garnick MB, Bubley G, DeWolf WC. Risk stratification and validation of prostate specific antigen density as independent predictor of progression in men with low risk prostate cancer during active surveillance. J Urol. 2011; 185: 471-6. https://doi. org/10.1016/j.juro.2010.09.115.

67. Tosoian JJ, Loeb S, Epstein JI, Turkbey B, Choyke PL, Schaeffer EM. Active Surveillance of Prostate Cancer: Use, Outcomes, Imaging, and Diagnostic Tools. Am Soc Clin Oncol Educ Book. 2016; 35: e235-45. https://doi. org/10.14694/EDBK_159244.

68. Catalona WJ, Partin AW, Sanda MG, Wei JT, Klee GG, Bangma CH, Slawin KM, Marks LS, Loeb S, Broyles DL, Shin SS, Cruz AB, Chan DW, et al. A multicenter study of [-2]pro-prostate specific antigen combined with prostate specific antigen and free prostate specific antigen for prostate cancer detection in the 2.0 to $10.0 \mathrm{ng} / \mathrm{ml}$ prostate specific antigen range. J Urol. 2011; 185: 1650-5. https:// doi.org/10.1016/j.juro.2010.12.032.

69. Loeb S, Sanda MG, Broyles DL, Shin SS, Bangma CH, Wei JT, Partin AW, Klee GG, Slawin KM, Marks LS, van Schaik RH, Chan DW, Sokoll LJ, et al. The prostate health index selectively identifies clinically significant prostate cancer. J Urol. 2015; 193: 1163-9. https://doi.org/10.1016/j. juro.2014.10.121.

70. Tosoian JJ, Loeb S, Feng Z, Isharwal S, Landis P, Elliot DJ, Veltri R, Epstein JI, Partin AW, Carter HB, Trock B, Sokoll LJ. Association of [-2]proPSA with biopsy reclassification during active surveillance for prostate cancer. J Urol. 2012; 188: 1131-6. https://doi.org/10.1016/j.juro.2012.06.009.

71. Hirama H, Sugimoto M, Ito K, Shiraishi T, Kakehi Y. The impact of baseline [-2]proPSA-related indices on the prediction of pathological reclassification at 1 year during active surveillance for low-risk prostate cancer: the Japanese multicenter study cohort. J Cancer Res Clin Oncol. 2014; 140: 257-63. https://doi.org/10.1007/ s00432-013-1566-2.

72. Kumar NB, Pow-Sang J, Spiess PE, Park J, Salup R, Williams CR, Parnes H, Schell MJ. Randomized, placebo-controlled trial evaluating the safety of one-year administration of green tea catechins. Oncotarget. 2016; 7: 70794-802. https://doi.org/10.18632/oncotarget.12222.

73. Andriole GL, Bostwick DG, Brawley OW, Gomella LG, Marberger M, Montorsi F, Pettaway CA, Tammela TL, Teloken C, Tindall DJ, Somerville MC, Wilson TH, Fowler IL, et al. Effect of dutasteride on the risk of prostate cancer. N Engl J Med. 2010; 362: 1192-202. https://doi. org/10.1056/NEJMoa0908127.

74. Hamilton RJ, Kahwati LC, Kinsinger LS. Knowledge and use of finasteride for the prevention of prostate cancer. 
Cancer Epidemiol Biomarkers Prev. 2010; 19: 2164-71. https://doi.org/10.1158/1055-9965.EPI-10-0082.

75. Lippman SM, Klein EA, Goodman PJ, Lucia MS, Thompson IM, Ford LG, Parnes HL, Minasian LM, Gaziano JM, Hartline JA, Parsons JK, Bearden JD 3rd, Crawford ED, et al. Effect of selenium and vitamin $\mathrm{E}$ on risk of prostate cancer and other cancers: the Selenium and Vitamin E Cancer Prevention Trial (SELECT). JAMA. 2009; 301: 39-51. https://doi.org/10.1001/jama.2008.864.
76. Parsons JK, Pierce JP, Mohler J, Paskett E, Jung SH, Humphrey P, Taylor JR, Newman VA, Barbier L, Rock CL, Marshall J. A randomized trial of diet in men with early stage prostate cancer on active surveillance: rationale and design of the Men's Eating and Living (MEAL) Study (CALGB 70807 [Alliance]). Contemp Clin Trials. 2014; 38: 198-203. https://doi.org/10.1016/j.cct.2014.05.002. 